\title{
Foraminiferal zonation of early Oligocene deposits (Selztal Group, Latdorfian, Rupelian) in the Mainz Basin, Germany
}

\author{
KIRSTEN I. GRIMM \\ Johannes Gutenberg-Universität, Institut für Geowissenschaften, LE Paläontologie, D-55099 Mainz, Germany \\ (e-mail: kgrimm@mail.uni-mainz.de).
}

\begin{abstract}
The foraminiferal zonation reported here is valid for the marine Oligocene deposits in the Mainz Basin. Thirteen zones and one subzone are defined in the basin facies, which may be correlated biostratigraphically with the current nannoplankton zones and also lithostratigraphically. The zonation for the beach facies, already described by the present author, is incorporated into the scheme. It is possible, therefore, to generate a high resolution foraminiferal biostratigraphical subdivision of the marine Oligocene deposits of the Mainz Basin. J. Micropalaeontol. 21(1): 67-74, May 2002.
\end{abstract}

\section{INTRODUCTION}

The Lower Oligocene deposits of the Mainz Basin (sensu Golwer, 1968) are composed of siliciclastic sediments comprising the Pechelbronn Beds, the Bodenheim, the Alzey and the Stadecken formations and the lower part of the Sulzheim Formation, as reported by Grimm et al. (2000). The Bodenheim, Alzey, Stadecken and Sulzheim formations are combined with the Budenheim Formation of Chattian age (Schäfer \& Kadolsky, 1998), to form the Selztal Group (Grimm et al., 2000). The stratigraphic sections examined (Fig. 1) ranged from the Middle Pechelbronn Beds at the base to the Stadecken Formation at the top (see Fig. 2). The marine-brackish to limnic Pechelbronn Beds, first described lithologically by Steuer (1910), in the Mainz Basin have previously not been studied biostratigraphically in detail, but they were investigated by Barth (1969) in the Rhine Graben at the locality of Rot-Malsch.

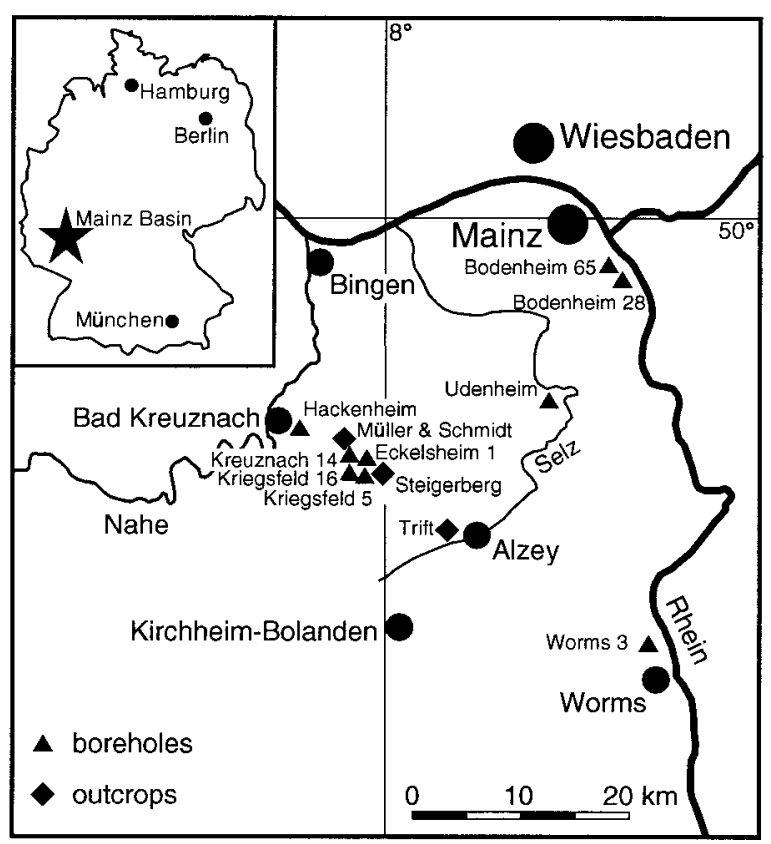

Fig. 1. Map of the Mainz Basin with location of boreholes and outcrops.
The basal clays of the Bodenheim Formation, formerly known as Rupelton, were first investigated biostratigraphically and subdivided by Spandel (1909) into the Lower Rupelton (=Foraminiferenmergel), the Middle Rupelton (Fischschiefer) and the Upper Rupelton. Additional studies made by Doebl (1956), Volk (1956), Thursch (1956) and Sonne (1988) have been followed by detailed biostratigraphical work by Grimm (1991, 1994, 1998).

The coastal gravels and sands of the Alzey Formation, formerly known as Meeressand, were first subdivided into two foraminiferal zones by Grimm (1998).

The Stadecken Formation, the former Schleichsand, has been investigated by Sonne (1988) and Kammerer (1993).

The biostratigraphical zonation based on foraminifera reported herein summarizes the detailed studies carried out during the last ten years on a collection of samples from more than 100 outcrops and boreholes, and updates this zonation not only to a modern international standard, but also combines a modern lithostratigraphical subdivision of the Mainz Basin with a detailed foraminiferal zonation.

\section{DEFINITION OF FORAMINIFERAL ZONES}

The following foraminiferal zones (Figs 2 and 3) are defined as biozones according to Salvador (1994) and Steininger \& Piller (1999). In the present study, 13 Biozones and 1 Subzone are established.

The studied stratigraphic section comprises the upper part of the international smaller benthic foraminiferal zone NSR $7 \mathrm{a}=$ Zone of Adercotryma agterbergi and the major part of NSR $7 \mathrm{~b}=$ Zone of Turrilina alsaticaafter Hardenbol et al. (1998). Adercotryma agterbergi, a very small species, is seldom present in the sediments of the middle Pechelbronn Beds of the Mainz Basin because of environmental reasons. Turrilina alsatica is widespread in the deposits of the Mainz Basin, and first appears at the base of the Bodenheim Formation and concomitantly at the base of the Alzey Formation. Hansenisca soldanii was mentioned in older publications but this species has subsequently been assigned to the genus Gyroidina following Kuhn (2000a). The biostratigraphic zonation is correlated with the nannoplankton zones of Martini \& Müller (1971). A list of the foraminifera is included in the Appendix and the range of the important species in the biozones is illustrated in Figure 3. 


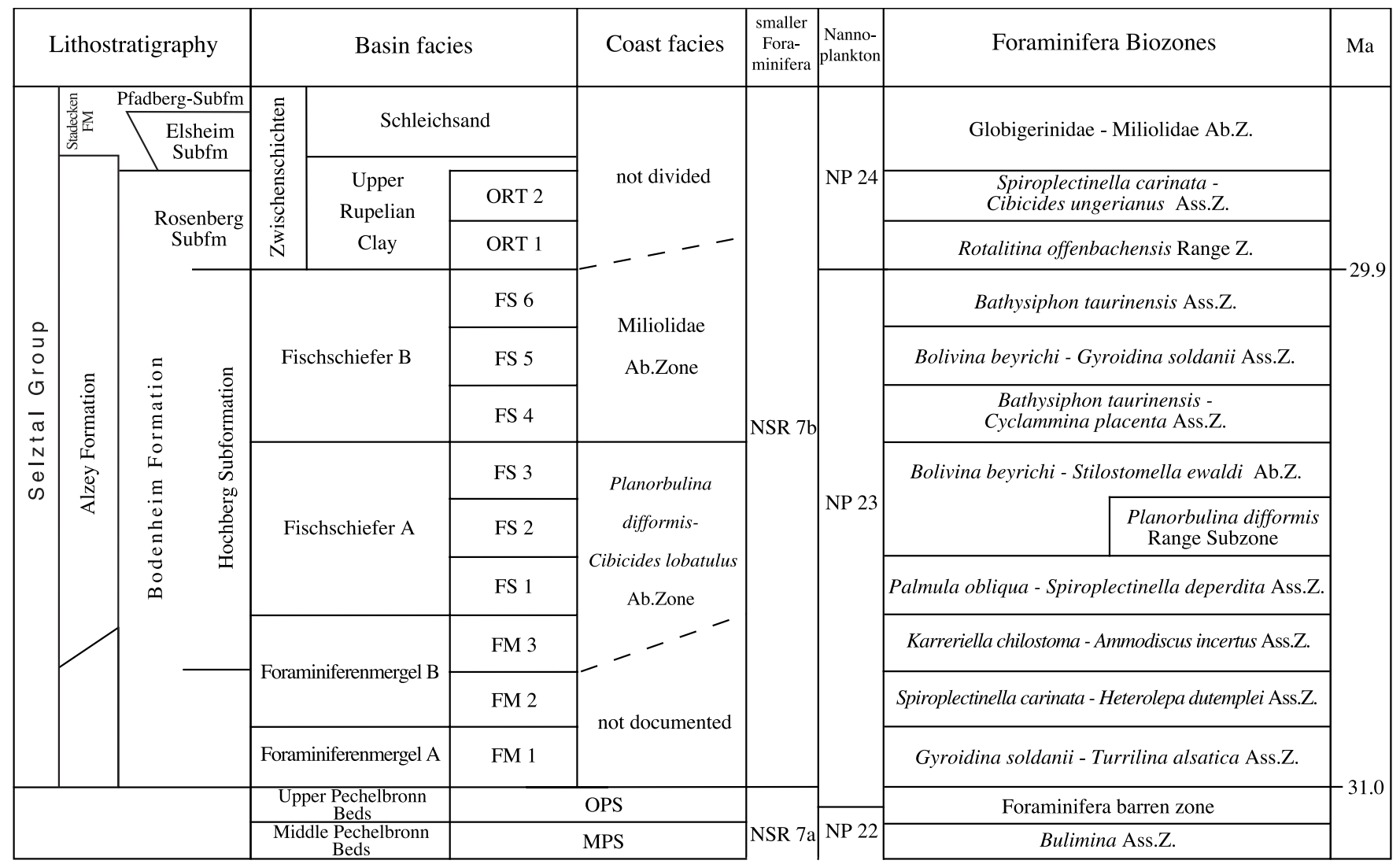

Fig. 2. Correlation of the foraminiferal biozones to the lithostratigraphy and other zonations.

\section{BASIN FACIES}

The following biozones are all valid for the Rupelian basin facies of the Mainz Basin.

\section{Bulimina Assemblage Zone}

Definition. This zone is defined by the first occurrence of Buliminidae in the Mainz Basin. Important species are Buliminella elegantissima, Bulimina coprolithoides, Bulimina elongata. The upper limit is marked by the disappearance of foraminifera. Adercotryma agterbergi occurs occasionally in low numbers in this zone.

Chronostratigraphy. Latdorfian, Oligocene.

Biostratigraphic correlation. This zone is equivalent to the upper part of NP 22.

Lithostratigraphic correlation. Middle Pechelbronn Beds.

Characteristic sites. Borehole Bodenheim 1965 (TK 256015 Mainz R 3451460 H 5533470), borehole Udenheim (TK 256115 Undenheim R 3442480 H 5525070).

\section{Foraminifera barren Zone}

Definition. Due to the limnic character of the Upper Pechelbronn Beds foraminifera are lacking.
Chronostratigraphy. Latdorfian, Oligocene.

Biostratigraphic correlation. By correlation to the Upper Rhine Graben brackish Upper Pechelbronn Beds the NP22/NP23 boundary is situated within this zone (Martini 1990).

Lithostratigraphic correlation. Upper Pechelbronn Beds.

Characteristic sites. Borehole Bodenheim 1965 (TK 256015 Mainz R 3451460 H 5533470), borehole Udenheim (TK 256115 Undenheim R 3442480 H 5525070).

\section{Gyroidina soldanii-Turrilina alsatica Assemblage Zone}

Definition. This zone is characterized by a low diversity foraminiferal fauna. The abundance of foraminifera is also low. The basal limit is marked by the new appearence of foraminifera after the underlying foraminiferal barren zone. At the upper limit, an increase in foraminifera is observed. Gyroidina soldanii is the dominant species of this zone, and Turrilina alsatica is first recorded at the base.

Chronostratigraphy. Rupelian, Oligocene.

Biostratigraphic correlation. This zone is a synonym of FM 1 of Grimm $(1994,1998)$ and is equivalent to the lower part of the NP 23 Zone. 
Foraminiferal zonation of the Oligocene in the Mainz Basin

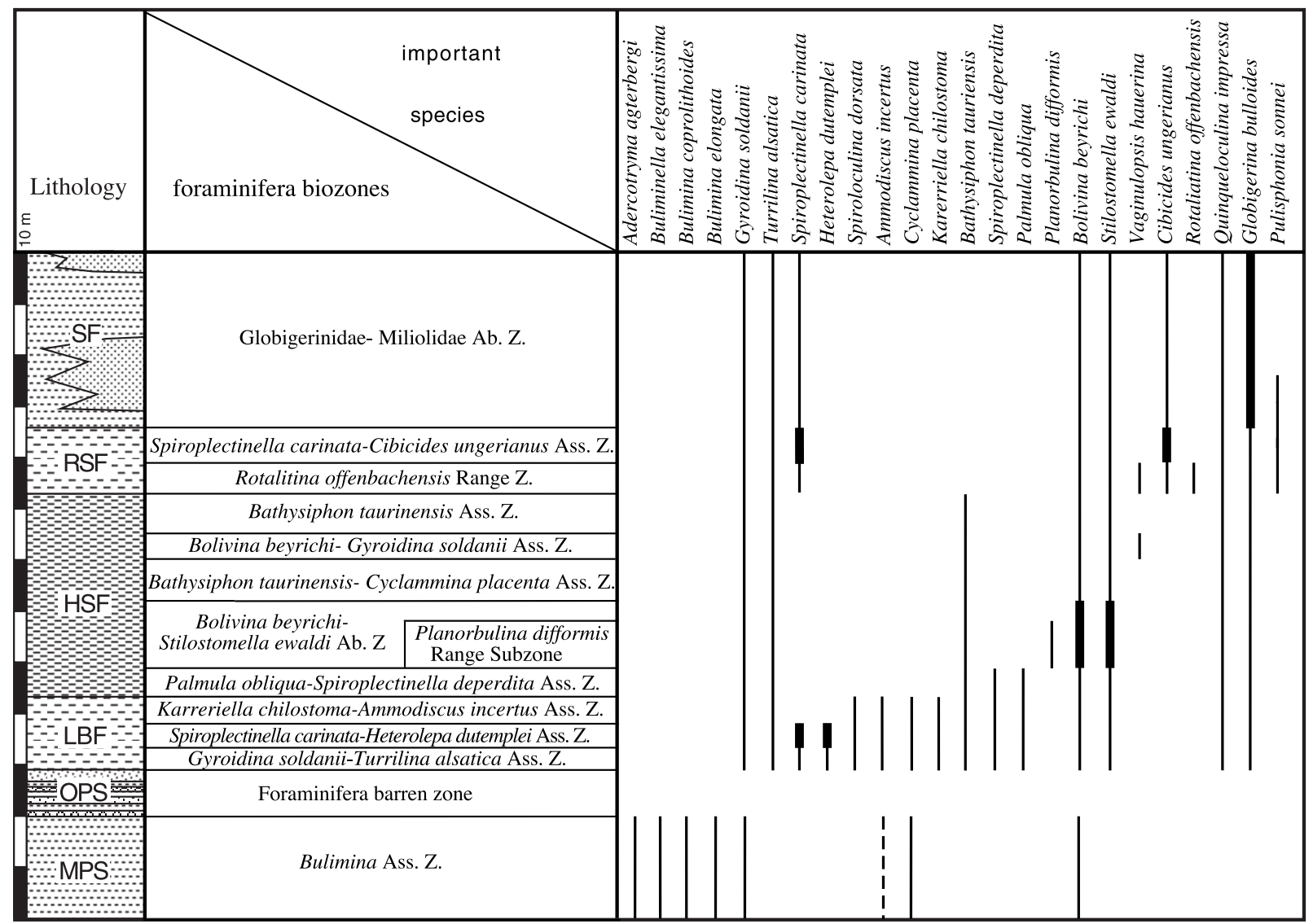

Fig. 3. Range of important species in the foraminiferal biozones. MPS, marls and claystones of the Middle Pechelbronn Beds; OPS, siltstones, sandstones and gravel beds of the Upper Pechelbronn Beds; LBF, claystones of the Lower Bodenheim Formation, HSF, bituminous claystones of the Hochberg Sub-formation; RSF, claystones of the Rosenberg Sub-formation; SF, fine sands and siltstones of the Stadecken Formation.

Lithostratigraphic correlation. Lower part of the Bodenheim Formation; former Lower Rupelian Clay.

Characteristic sites. Borehole Bodenheim 1965 (TK 256015 Mainz R 3451460 H 5533470), borehole Udenheim (TK 256115 Undenheim R 3442480 H 5525070).

\section{Spiroplectinella carinata-Heterolepa dutemplei Assemblage Zone}

Definition. This zone is characterized by a rich foraminiferal fauna and by the presence of a large number of individuals with agglutinated tests. It is defined by the common appearance of Spiroplectinella carinata and Heterolepa dutemplei. Spiroloculina dorsata, Ammodiscus incertus and Karreriella chilostoma are also found. The lower limit is marked by a sudden increase in foraminifera. The upper limit is defined by the disappearence of Spiroplectinella carinata and Heterolepa dutemplei.

Chronostratigraphy. Rupelian, Oligocene.

Biostratigraphic correlation. This zone is a synonym of the FM 2 Zone of Grimm $(1994,1998)$ and is equivalent to the NP 23 Zone.
Lithostratigraphic correlation. Lower part of the Bodenheim Formation; former Lower Rupelian Clay.

Characteristic sites. Borehole Bodenheim 1965 (TK 256015

Mainz R 3451460 H 5533470), borehole Udenheim (TK 256115 Undenheim R 3442480 H 5525070).

\section{Karreriella chilostoma-Ammodiscus incertus Assemblage Zone}

Definition. The occurrence of Spiroloculina dorsata, Ammodiscus incertus and Karreriella chilostoma are characateristic of this zone. The frequency of agglutinated tests is very high. The lower limit is marked by the disappearance of Spiroplectinella carinata and Heterolepa dutemplei, which are both characteristic species of the underlying zone. At the upper limit the numbers of agglutinated tests decreases.

Chronostratigraphy. Rupelian, Oligocene.

Biostratigraphic correlation. This zone is a synonym of the FM 3 Zone of Grimm $(1994,1998)$ and is equivalent to part of the NP 23 Zone. 
Lithostratigraphic correlation. Bodenheim Formation, Hochberg Sub-formation; former Lower Rupelian Clay.

Characteristic sites. Borehole Bodenheim 1965 (TK 256015 Mainz R 3451460 H 5533470), borehole Hackenheim (TK 25 6113 Bad Kreuznach R 3421520 H 5522000).

\section{Palmula obliqua-Spiroplectinella deperdita Assemblage Zone}

Definition. This zone is characterized by the occurrence of Palmula obliqua and Spiroplectinella deperdita. Spiroplectinella deperdita is also recorded in the lower zones, Palmula obliqua can also be found in lower zones occasionally, but both disappear at the top of this zone. The upper limit is defined by the disappearance of Spiroplectinella deperdita. The lower limit is characterized by the marked decrease in the number of agglutinated tests.

Chronostratigraphy. Rupelian, Oligocene.

Biostratigraphic correlation. This zone is a synonym of the FS 1 Zone of Grimm $(1991,1994)$ and is equivalent to part of the NP 23 Zone.

Lithostratigraphic correlation. Bodenheim Formation, Hochberg Sub-formation; former Middle Rupelian Clay.

Characteristic sites. Borehole Bodenheim 28 (TK 256015 Mainz R 3450060 H 5530435), borehole Kriegsfeld 16 (TK 256213 Kriegsfeld R 3425335 H 5517535).

\section{Bolivina beyrichi-Stilostomella ewaldi Abundance Zone}

Definition. Bolivina beyrichi and Stilostomella ewaldi occur in large numbers within this zone. Additional characteristic species are Cyclammina placenta?, Bathysiphon taurinensis and Gyroidina soldanii. Spiroplectinella deperdita and Palmula obliqua disappear at the beginning of this zone. At the end of this zone a sudden decrease in foraminiferal diversity can be observed. Within this zone, a subzone can be established, based on the occurrence of Planorbulina difformis.

Chronostratigraphy. Rupelian, Oligocene.

Biostratigraphic correlation. This zone is a synonym of the FS 2 and FS 3 Zones of Grimm $(1991,1994)$ and is equivalent to part of the NP 23 Zone.

Lithostratigraphic correlation. Bodenheim Formation, Hochberg Sub-formation; former Middle Rupelian Clay.

Characteristic sites. Borehole Bodenheim 28 (TK 256015 Mainz R 3450060 H 5530435), borehole Udenheim (TK 256115 Undenheim R 3442480 H 5525070).

\section{7a. Planorbulina difformis Range Subzone}

Definition. The Planorbulina difformis Range Subzone is defined by the occurrence of Planorbulina difformis within the lower part of the Bolivina beyrichi-Stilostomella ewaldi Abundance Zone.
Chronostratigraphy. Rupelian, Oligocene.

Biostratigraphic correlation. This zone is a synonym of the FS 2 Zone of Grimm $(1991,1994)$ and equivalent to part of the NP 23 Zone.

Lithostratigraphic correlation. Bodenheim Formation, Hochberg Sub-formation; former Middle Rupelian Clay.

Characteristic site. Borehole Kriegsfeld 5 (TK 256213 Kriegsfeld R 3425790 H 5516785).

\section{Bathysiphon tauriensis-Cyclammina placenta Assemblage Zone}

Definition. This zone is marked by a generally impoverished foraminiferal fauna. A few species (Bathysiphon taurinensis and Cyclammina placenta) extend throughout the zone. The lower limit is characterized by the disappearance of the rich foraminiferal fauna of the underlying zone. The upper limit is characterized by the sudden rise of a more diverse fauna. The Bathysiphon tauriensis-Cyclammina placenta Assemblage Zone can be recognized in species-richness diagrams from its reduced species diversity (Grimm, 1994).

Chronostratigraphy. Rupelian, Oligocene.

Biostratigraphic correlation. This zone is a synonym of the FS 4 Zone of Grimm $(1991,1994)$ and is equivalent to part of the NP 23 Zone.

Lithostratigraphic correlation. Bodenheim Formation, Hochberg Sub-formation; former Middle Rupelian Clay.

Characteristic sites. Borehole Bodenheim 1965 (TK 256015 Mainz R 3451460 H 5533470), borehole Udenheim (TK 256115 Undenheim R 3442480 H 5525070).

\section{Bolivina beyrichi-Gyroidina soldanii Assemblage Zone}

Definition. The zone is marked by a brief increase in diversity within an otherwise impoverished section. Occasionally Vaginulopsis hauerina may be recorded. The lower limit is characterized by the increase, and the upper limit by the decrease in foraminifera.

Chronostratigraphy. Rupelian, Oligocene.

Biostratigraphic correlation. This zone is a synonym of the FS 5 Zone of Grimm $(1991,1994)$ and is equivalent to part of the NP 23 Zone.

Lithostratigraphic correlation. Bodenheim Formation, Hochberg Sub-formation; former Middle Rupelian Clay.

Characteristic sites. Borehole Bodenheim 1965 (TK 256015 Mainz R 3451460 H 5533470), borehole Udenheim (TK 256115 Undenheim R 3442480 H 5525070). 


\section{Bathysiphon tauriensis Assemblage Zone}

Definition. This zone is very poor in foraminifera. Only rare specimens of Cyclammina placenta and Bathysiphon taurinensis occur. The lower limit is defined by a sudden decrease in foraminfera. The upper limit is characterized by the disappearance of Bathysiphon taurinensis and the beginning of a more diverse foraminiferal fauna.

Chronostratigraphy. Rupelian, Oligocene.

Biostratigraphic correlation. This zone is a synonym of the FS 6 Zone of Grimm $(1991,1994)$ and is equivalent to the upper part of the NP 23 Zone. The upper boundary of the NP 23 Zone is at the top of this zone.

Lithostratigraphic correlation. Bodenheim Formation, Hochberg Sub-formation, former Middle Rupelian Clay.

Characteristic sites. Borehole Bodenheim 1965 (TK 256015 Mainz R 3451460 H 5533470), borehole Udenheim (TK 256115 Undenheim R 3442480 H 5525070).

\section{Rotaliatina offenbachensis Range Zone}

Definition. The lower limit of this zone is defined by the appearance of Rotaliatina offenbachensis, with the upper limit marked by the disappearance of Rotaliatina offenbachensis and Vaginulopsis hauerina. Pulsiphonina sonnei first appears in this zone. Furthermore, this zone is characterized by a moderately diverse benthonic foraminiferal fauna, which is much increased after the impoverished fauna of zones 8 to 10 .

Chronostratigraphy. Rupelian, Oligocene.

Biostratigraphic correlation. This zone is a synonym of the ORT 1 Zone of Grimm (1994) and is equivalent to the base of the NP 24 Zone.

Lithostratigraphic correlation. Bodenheim Formation, Rosenberg Sub-formation, former Upper Rupelian Clay.

Characteristic sites. Borehole Bodenheim 1965 (TK 256015 Mainz R 3451460 H 5533470), borehole Udenheim (TK 256115 Undenheim R 3442480 H 5525070).

\section{Spiroplectinella carinata-Cibicides ungerianus Assemblage Zone}

Definition. This zone is characterized by the common occurrence of Spiroplectinella carinata and Cibicides ungerianus. The lower limit is marked by the disappearance of Rotaliatina offenbachensis and Vaginulopsis hauerina and the upper limit by the appearance of a reduced fauna with small individuals. Older reworked foraminifera coming from the Alps appear within this zone.

Chronostratigraphy. Rupelian, Oligocene.

Biostratigraphic correlation. This zone is a synonym of the ORT 2 Zone of Grimm (1994) and is equivalent to part of the NP 24 Zone.
Lithostratigraphic correlation. Bodenheim Formation, Rosenberg Sub-formation; former Upper Rupelian Clay.

Characteristic sites. Borehole Bodenheim 1965 (TK 256015 Mainz R 3451460 H 5533470), borehole Udenheim (TK 256115 Undenheim R 3442480 H 5525070).

\section{Globigerinidae-Miliolidae Abundance Zone}

Definition. The Globigerinidae-Miliolidae Abundance Zone is characterized by large numbers of Globigerinidae and Miliolidae. Many of the Globigerinidae are represented by specimens of Globigerina bulloides. Among the Miliolidae, Quinqueloculina impressa is the most frequent taxon. The entire foraminiferal fauna is neither abundant nor diverse. Pulsiphonina sonnei disappears within this zone. Polymorphinidae may also occur in large numbers. This zone is also characterized by the appearance of older reworked foraminifera (see above).

Chronostratigraphy. Rupelian, Oligocene.

Biostratigraphic correlation. NP 24.

Lithostratigraphic correlation. Stadecken Formation and Bodenheim Formation, Rosenberg Sub-formation; former Schleichsand.

Characteristic site. Borehole Udenheim (TK 256115 Undenheim R 3442480 H 5525070).

\section{BEACH FACIES}

For the beach facies the following two biozones were established by Grimm (1998).

\section{Planorbulina difformis-Cibicides lobatulus Abundance Zone}

Definition. The Planorbulina difformis-Cibicides lobatulus Abundance Zone is characterized by large numbers of Planorbulina difformis ( $>40 \%$ of the foraminiferal assemblage) and Cibicides lobatulus. The lower limit is defined by the appearance of foraminifera in the beach facies of the Mainz Basin. The upper limit is characterized by the increase in individuals of the Miliolidae.

Chronostratigraphy. Rupelian, Oligocene.

Biostratigraphic correlation. A correlation with the basin facies is possible, so this zone corresponds to FS A and parts of FM 3 of Grimm $(1991,1994,1998)$ or to biozones 5 to 7 established above.

Lithostratigraphic correlation. Alzey Formation; former lower Meeressand.

Characteristic sites. Sand pit Steigerberg near Eckelsheim (TK 25, 6213 Kriegsfeld R 3427220 H 5517175), sand pit Müller \& Schmidt Wöllstein (TK 25, 6113 Bad Kreuznach R 3424010 H 5519600). 
Miliolidae Abundance Zone

Definition. The Miliolidae Abundance Zone is characterized by large numbers of miliolids. Some characteristic species are Quinqueloculina triangularis, Quinqueloculina aknerianus, Spiroloculina dorsata and Cycloforina contorta. The lower limit is defined by the increase in miliolids and the decrease in Planorbulina difformis. The upper limit is marked by the end of the beach deposits in the Mainz Basin.

Chronostratigraphy. Rupelian, Oligocene.

Biostratigraphic correlation. A correlation with the basin facies is possible, so this zone corresponds to FS B and perhaps to ORT 1 of Grimm $(1991,1994,1998)$ or to the biozones 8 to 11 established above.

Lithostratigraphic correlation. Alzey Formation; former lower Meeressand.

Characteristic sites. Sand pit Steigerberg near Eckelsheim (TK 25, 6213 Kriegsfeld R 3427220 H 5517175), former sand pit and natural monument Trift at Alzey-Weinheim (TK 25, 6214 Alzey R 3433200 H 5511900).

\section{CONCLUSION}

A detailed biostratigraphical subdivision for the Mainz Basin is established, based on foraminifera. The foraminiferal fauna reflects not only the stratigraphic succession but also the marked changes in ecology. This zonation is only valid for the small area of the Mainz Basin that experienced fully marine conditions during the Latdorfian and Rupelian. This has been correlated accurately with the nannoplankton zones of Martini \& Müller (1971).

\section{ACKNOWLEDGEMENTS}

The author wishes to thank the Geologisches Landesamt Rheinland-Pfalz for permission to study their micropalaeontological collection. I am grateful to T. Griessemer (Mainz) for samples and information about the Pechelbronn Beds. I also thank my husband, Dr M. Grimm (Mainz) and Dr C. Mödden (Mainz) for critically reviewing the manuscript. This work was supported by a grant from the Deutsche Forschungsgemeinschaft (Gr 1431/2-1 \& /2-2).

\section{Manuscript received 30 January 2001 Manuscript accepted 1 January 2002}

\section{REFERENCES}

Barth, S. 1969. Feinstratigraphische und mikropaläontologische Untersuchungen an der Grenze Eozän/Oligozän im Tertiär des Rheingrabens (Pechelbronner Schichten von Rot-Malsch). PhD thesis, Heidelberg.

Doebl, F. 1954. Mikrofaunistische Untersuchungen an der Grenze Rupelton - Schleichsand (Mitteloligozän) im Mainzer Becken. Notizblatt des hessischen Landesamtes für Bodenforschung, 82: 57-111.

Doebl, F. \& Malz, H. 1962. Tertiär des Rheintal-Grabens. Arbeitskreis deutscher Mikropaläontologen. Leitfossilien der Mikropaläontologie, 379-398.

Golwer, A. 1968. Paläogeographie des Hanauer Beckens im Oligozän und Miozän. Notizblatt des hessischen Landesamtes für Bodenforschung, 96: 157-184.
Gradstein, F.M. \& Kaminski, M.A. 1989. Taxonomy and biostratigraphy of new and emended species of Cenozoic deep-water agglutinated foraminifera from the Labrador and North Seas. Micropaleontology, 35(1): 72-92.

Grimm, K.I. 1991. Biostratigraphie, Paläogeographie und Paläoökologie des Fischschiefers (Mittlerer Rupelton/Mitteloligozän) im Mainzer Becken. Mainzer geowissenschaftliche Mitteilungen, 20: 249-278.

Grimm, K.I. 1994. Paläoökologie, Paläogeographie und Stratigraphie im Mainzer Becken, im Oberrheingraben, in der Hessischen Senke und in der Leipziger Bucht während des Mittleren Rupeltons (Fischschiefer / Rupelium / Unteroligozän). Mitteilungen der Pollichia, 81: 7-193.

Grimm, K.I. 1998. Correlation of Rupelian coastal and basin facies in the Mainz Basin (Oligocene, Germany). Neues Jahrbuch für Geologie und Paläontologie Monatshefte, 3, 1998: 146-156.

Grimm, K.I., Grimm, M.C. \& Schindler, T. 2000. Lithostratigraphische Gliederung im Rupelium / Chattium des Mainzer Beckens. Deutschland. Neues Jahrbuch für Geologie und Paläontologie Abhandlungen, 3, 218: 343-397.

Hardenbol, J., Thierry, J., Farley, M.B., Jacquin, T., de Graciansky, P.-C. \& Vail, P.R. 1998. Cenozoic biochronostratigraphy. In de Graciansky, P.-C., Hardenbol, J., Jacquin, T. \& Vail, P.R. (Eds), Mesozoic and Cenozoic sequence stratigraphy of European basins. SEPM Special Publication, 60.

Kammerer, T. 1993. Ostracoden aus dem Oberen Rupelton, Schleichsand und Cyrenenmergel (Zwischenschichten, Rupelium bis unteres Chattium) des Mainzer Beckens. PhD thesis, Mainz.

Kuhn, W. 2000a. Pulsiphonina sonnei n.sp., eine neue Foraminifern-Art aus dem Oberen Rupelton (Oligozän) des Mainzer Beckens. Jahresberichte und Mitteilungen des oberrheinischen geologischen Vereins, Neue Folge, 82: 245-250.

Kuhn, W. 2000b. Gyroidina-Gyroidinoides-Hansenisca Validitätsprobleme der Foraminiferengruppe. Münchener Geowissenschaftliche Abhandungen (A), 39: 47-50.

Loeblich, A. \& Tappan, H. 1988. Foraminiferal genera and their classification. Van Nostrand, New York.

Martini, E. 1990. The Rhinegraben system, a connection between northern and southern seas in the European Tertiary. Veröffentlichungen des Übersee-Museums, A10: 83-98.

Martini, E. \& Müller, C. 1971. Das marine Alttertiär in Deutschland und seine Einordnung in die Standard-Nannoplankton-Zonen. Erdöl, Kohle, 24: 381-384.

Papp, A. \& Schmid, M.F. 1985. Die fossilen Foraminiferen des tertiären Beckens von Wien. Abhandlungen der Geologischen Bundesanstalt, 37: $1-311$.

Salvador, A. 1994. International Stratigraphic Guide (A Guide to Stratigraphic Classification Terminology and Procedure) 2nd edn.

Schäfer, P. \& Kadolsky, D. 1998. Zur Gliederung eines Tertiärprofils von Budenheim bei Mainz, insbesondere zur stratigraphischen Stellung und Genese der "Milchquarzschotter" (Oberoligozän) im nordwestlichen Rheinhessen (Mainzer Becken). Mainzer naturwissenschaftliches Archiv/ Beiheft, 21: 115-132.

Sonne, V. 1988. Oberer Rupelton, Schleichsand (Rupel) und Cyrenenmergel (tiefes Chatt) im Mainzer Becken: Können sie mikropaläontologisch definiert werden? Mainzer geowissenschaftliche Mitteilungen, 17: 19-30.

Spandel, E. 1909. Der Rupelton des Mainzer Beckens, seine Abteilungen und deren Foraminiferenfauna, sowie einige weitere geologischpaläontologische Mitteilungen über das Mainzer Becken. Berichte des Offenbacher Vereins für Naturkunde, 43-50: 57-230.

Steininger, F.F. \& Piller;, W.E. 1999. Empfehlungen (Richtlinien) zur Handhabung der stratigraphischen Nomenklatur. Courier des Forschungsinstitutes Senckenberg, 209: 1-19.

Steuer, A. 1910. Geologischer Führer durch das Großherzogtum Hessen für die Teilnahme an der 55. Versammlung der Deutschen Geologischen Gesellschaft zu Darmstadt im August 1911. III. Kurze Beschreibung des Tertiär im Mainzer Becken und Führer für vier Exkursionstage. Notizblatt des hessischen Vereins für Erdkunde und der Hessischen Geologischen Landesanstalt (IV), 31: 34-62.

Thursch, H. 1956. Die Gliederung des Unteren Rupeltons im Mainzer Becken auf Grund seiner Foraminiferenfauna. Notizblatt des hessischen Landesamtes für Bodenforschung, 84: 216-231. 
Volk, C. 1956. Die Foraminiferen des Rupeltons des Mainzer Beckens. $\mathrm{PhD}$ thesis, Frankfurt.

\section{Appendix}

The foraminiferal species mentioned below are listed in alphabetical order with references to descriptions and illustrations.

Adercotryma agterbergi Gradstein \& Kaminski, 1989: Gradstein \& Kaminski, 1989, p. 73, pl. 1, fig. 1a-5c; pl. 2, fig. 1a-3b.

Ammodiscus incertus (d'Orbigny, 1839): this paper, Pl. 1, fig. 10.

Bathysiphon tauriensis Sacco, 1893: this paper, Pl. 1, fig. 13.

Bolivina beyrichi Reuss, 1851: this paper, P1. 1, fig. 8.

Bulimina coprolithoides Andreae, 1884: Doebl \& Malz (1962), p. 386 , pl. 56 , fig. 3 .

Bulimina elongata d'Orbigny, 1846: Papp \& Schmid (1985), p. 73, pl. 63, figs 5-9.

Buliminella elegantissima (d'Orbigny, 1839): Loeblich \& Tappan (1988), p. 522, pl. 572, figs 7-11.

Cibicides ungerianus (d'Orbigny, 1846): Grimm (1994), p. 81, pl. 1, fig. 4.

Cyclammina placenta (Reuss, 1851): this paper, Pl. 1, fig. 12.
Globigerina bulloides d'Orbigny, 1826: Grimm (1991), pl. 1, fig.6.

Gyroidina soldanii (d'Orbigny, 1826): this paper, Pl. 1, fig. 1. Heterolepa dutemplei (d'Orbigny, 1846): this paper, Pl. 1, fig. 5 .

Karreriella chilostoma (Reuss, 1852): this paper, Pl. 1, fig. 4. Palmula obliqua (Roemer, 1838): this paper, Pl. 1, fig. 6.

Planorbulina difformis Roemer, 1838: this paper, Pl. 1, fig. 15. Pulisphonia sonnei Kuhn, 2000: Kuhn (2000b), p.246, figs1-6. Quinqueloculina impressa Reuss, 1851: this paper, Pl. 1, fig. 9. Rotaliatina offenbachensis Spandel, 1909: this paper, Pl. 1, fig. 14.

Spiroloculina dorsata Reuss, 1866: Grimm (1994), p. 67, pl. 2, fig. 3.

Spiroplectinella carinata (d'Orbigny, 1846): this paper, Pl. 1, fig. 3

Spiroplectinella deperita (d'Orbigny, 1846): this paper, Pl. 1, fig. 7.

Stilostomella ewaldi (Reuss, 1851): this paper, Pl. 1, fig. 11.

Turrilina alsatica Andreae, 1884: this paper, Pl. 1, fig. 2.

Vaginulopsis hauerina (d'Orbigny, 1846): Grimm (1994), p. 73 , pl. 1 , fig. 2 .

Fig. 1. Gyroidina soldanii, borehole Bodenheim 28, $90 \mathrm{~m}(6015 / 647 / 1)$. Fig. 2. Turrilina alsatica, borehole Bodenheim 65, $90 \mathrm{~m}(6015 / 1123)$. Fig. 3. Spiroplectinella carinata, borehole Bodenheim 65, $120 \mathrm{~m}$ (6015/1153/1). Fig. 4. Karreriella chilostoma, borehole Hackenheim, 146 m (6113/267/1). Fig. 5. Heterolepa dutemplei, borehole Kriegsfeld 16, $49 \mathrm{~m}$ (6213/661/1). Fig. 6. Palmula obliqua, borehole Bodenheim 65, 100 m (6015/1133/1). Fig. 7. Spiroplectinella deperdita, borehole Kriegsfeld 12, $16 \mathrm{~m}$ (6213/473/1). Fig. 8. Bolivina beyrichi, borehole Bodenheim 65, 90 m (6015/1123/1). Fig. 9. Quinqueloculina impressa, borehole Eckelheim 1, $39 \mathrm{~m} \mathrm{(6213/712/1).} \mathrm{Fig.} \mathrm{10.} \mathrm{Ammodiscus} \mathrm{incertus,} \mathrm{borehole} \mathrm{Bodenheim} \mathrm{65,} \mathrm{104} \mathrm{m}$ (6015/1137/1). Fig. 11. Stilostomella ewaldi, borehole Bodenheim 65, $83 \mathrm{~m}(6015 / 116 / 1)$. Fig. 12. Cyclammina placenta, borehole Worms 3, $1208 \mathrm{~m}$ (6316/3377/1). Fig. 13. Bathysiphon taurinensis, borehole Worms 3, 1236 m (6316/351/1). Fig. 14. Rotaliatina offenbachensis, borehole Bad Kreuznach 14, $16 \mathrm{~m}(6113 / 812 / 1)$. Fig. 15. Planorbulina difformis, borehole Bad Kreuznach 14, $31 \mathrm{~m}(6113 / 827 / 1)$. All specimens are deposited in the microfossil collection of the geological survey of Rheinland-Pfalz with the mentioned numbers. All scale bars $=100 \mu \mathrm{m}$. 


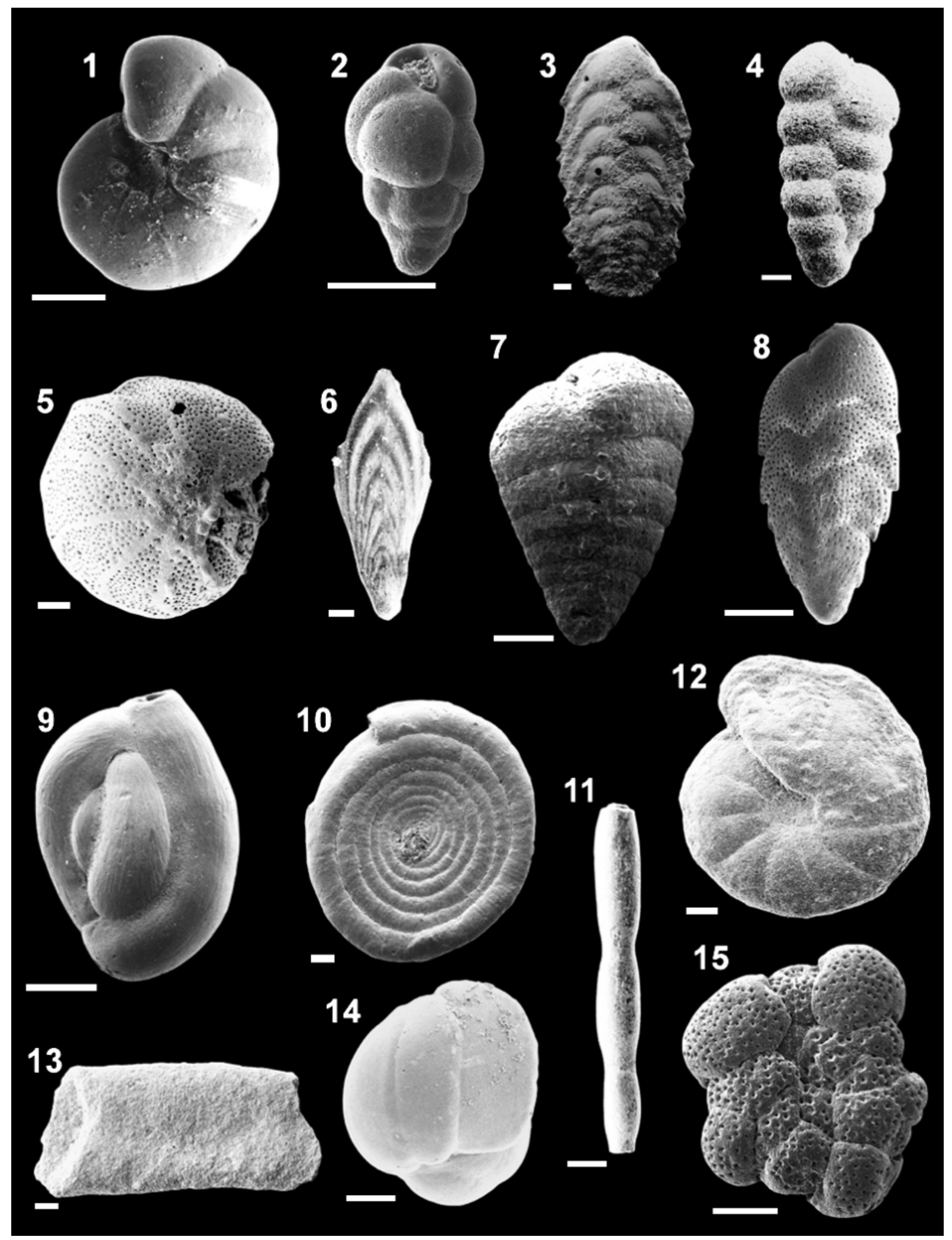

